\title{
Vladimir Mayakovsky and the Utopian Imagination in the Russian Revolution
}

\author{
M. D. Steinberg
}

For citation: Steinberg M. D. Vladimir Mayakovsky and the Utopian Imagination in the Russian Revolution. Vestnik of Saint Petersburg University. History, 2018, vol. 63, issue 1, pp. 83-91. https://doi. org/10.21638/11701/spbu02.2018.105

This article - the third part of a three-part series that reinterprets the "utopianism" of Russian revolutionaries, especially the Bolsheviks - focuses on the perspectives of Vladimir Mayakovsky. Part 1 described the basic theoretical approach: an alternative definition of the utopian imagination developed after 1917 in the work of Ernst Bloch, Walter Benjamin, Theodor Adorno, and others. In brief, this sees utopia as a critical analysis of conventional constructions of reality, time, and the possible: as a critical negation of that which merely is in the name of what should be, as a radical challenge to assumptions about what is possible and impossible in the present, as a vision of time and history as containing the possibility of an explosive "leap in the open air of history" (Benjamin). Utopian consciousness breaks into the normativized world of knowledge and expectations about reality and possibility in history to reveal the new and unexpected. This is utopia as radical epistemology, hermeneutics, and praxis. This article focuses on Vladimir Mayakovsky (the previous articles discussed Alexandra Kollontai and Lev Trotsky). Mayakovsky's poetry visualized both the oppressive darkness of the lived present and a world of possibility greater than the normativized reality of his own time. $\mathrm{He}$ offered a counterreality of "Vladimir Mayakovsky" as utopian antithesis to the merely factual reality of the present. He explored the conventional linear temporality of the world as given and the possibility of an explosive leap into the future. Time was particularly important for Mayakovsky's poetic thought and is a central theme in all utopian thought. Like Kollontai and Trotsky, Mayakovsky's utopian impulse collided with the stubbornness of the present, with the tenacious force of necessity. But the focus in all three articles has been on the spirit that led them to attempt to leap into the clear, free, and unpredictable open air of history. This utopian impulse was central to the experience of the Russian revolution for so many. We must recognize their utopian "leap" even as we acknowledge the dystopian and catastrophic landing.

Keywords: Vladimir Mayakovsky, the Russian revolution, utopianism, Russian revolutionaries.

\section{Владимир Маяковский и утопическое воображение в русской революции}

\section{М. Д. Стейнберг}

Для цитирования: Steinberg M.D. Vladimir Mayakovsky and the Utopian Imagination in the Russian Revolution // Вестник Санкт-Петербургского университета. История. 2018. Т. 63. Вып. 1. C. 83-91. https://doi.org/10.21638/11701/spbu02.2018.105

Steinberg Mark D. - PhD in History, Professor, University of Illinois, 309 Gregory Hall, 810 S. Wright Street, Urbana-Champaign, Illinois, 61801, USA; steinb@illinois.edu

Стейнберг Марк Д. - PhD, проф., Университет Иллинойса, США, 61801, Иллинойс, УрбанаШампейн, Грегори Холл 309, С. Райт 810, США; steinb@illinois.edu

(C) Санкт-Петербургский государственный университет, 2018 
Эта статья, завершающая серию из трех частей, переосмысливающую «утопизм» русских революционеров, особенно большевиков, фокусируется на перспективах Владимира Маяковского. В первой части описан базовый теоретический подход: альтернативное определение утопического воображения, разработанного после 1917 г. в работах Эрнста Блоха, Вальтера Беньямина, Теодора Адорно и др. Одним словом, в статье рассматривается утопия как критический анализ обычных построений реальности, времени и возможного, как радикальный вызов предположениям о том, что возможно и невозможно в настоящем, как видение времени и истории, содержащее возможность взрывного «прыжка на открытом воздухе истории» (Вальтер Беньямин ). Утопическое сознание проникает в нормализованный мир знаний и ожиданий о реальности и возможности в истории, раскрывая новое и неожиданное. Это утопия как радикальная эпистемология, герменевтика и практика. В данной статье основное внимание уделяется Владимиру Маяковскому (в предыдущих статьях обсуждались Александра Коллонтай и Лев Троцкий). Поэзия Маяковского визуализировала как гнетущую тьму живого настоящего, так и мир возможностей больше, чем нормализованная реальность его собственного времени. Он предложил контрреальность «Владимира Маяковского» как утопическую противоположность просто фактической реальности настоящего. Он исследовал обычную линейную временность мира как данность и возможность взрывного скачка в будущее. Время особенно важно для поэтической мысли Маяковского и является центральной темой во всей утопической мысли. Подобно Коллонтай и Троцкому, утопический импульс Маяковского столкнулся с противодействием настоящего, с упорной силой необходимости. Но основное внимание во всех трех статьях сосредоточено на духе, который заставил их попытаться проникнуть в ясный, свободный и непредсказуемый открытый мир. Этот утопический импульс был центральным в опыте русской революции для многих. Мы должны признать их утопический «прыжок», даже когда мы признаем неидеальное общество и катастрофическую землю.

Ключевые слова: Владимир Маяковский, русская революция, утопизм, русские революционеры.

The poet Vladimir Mayakovsky might seem an odd choice in a historical essay on Bolshevik utopianism. He was an even less orthodox Bolshevik, and not a political leader or theorist. But, I would suggest, he embodied in so many ways the spirit of the revolution, especially as lived experience and historical feeling. His poetic vocabulary, both in its excessive bluntness and its metaphoric allusiveness, takes us deeper into understanding this spirit and those times than prosaic discourse ${ }^{1}$. Victor Shklovsky described Mayakovsky's essential mood as a "spiritual craving", a desire for "a new sight and hearing" that could cut through the "contradictions of his time" 2

1 "Ia sam" (1922), in: Maiakovskii V. V. Izbrannye sochineniia. In 2 vols. Moscow, 1981. Vol. 1. P. $35-$ 50 (quotations p. 38, 40). The complete works in Russian are: Maiakovskii V. V. Polnoe sobranie sochinenii. In 13 vols. Moscow, 1955-1961. Available in the Fundamental Digital Library. URL: http://feb-web.ru/feb/ mayakovsky/default.asp?/feb/mayakovsky/texts/ms0/ms0.html (accessed 09.03.2017).

Major biographical and literary studies in English of Mayakovsky included: Brown E. Mayakovsky: A Poet in the Revolution. Princeton, 1973; Jangfeldt B. : 1) Majakovskij and Futurism, 1917-1921. Stockholm, 1976; 2) Mayakovsky: A Biography / transl. from Swedish by Harry Watson. Chicago, 2014; Terras V. Vladimir Mayakovsky. Boston, 1983. On "futurism," see especially: Markov V. Russian Futurism: A History. Berkeley, 1968 (reprinted Washington (D.C.), 2006); Perloff M. The Futurist Moment: Avant-Garde, Avant Guerre, and the Language of Rupture. Chicago, 2003; Gurianova N. The Aesthetics of Anarchy: Art and Ideology in the Early Russian Avant-Garde. Berkeley, 2012.

2 Shklovskii V.O Maiakovskom // Zhili-Byli: vospominaniia, memuarnye zapisi, povesti i vremeni, s kontsa XIX v po 1962 g. Moscow, 1964. P.216-217. 
Before 1917 Mayakovsky's poetry visualized what Bloch would call the "darkness of the lived present, the customary land of present reality" as a simultaneously symbolic and tangible world of cold fogs, dismal rains, and cutting winds (nature was an enemy, resisting human imagination and will), oppressive objects (smokestacks, windows, bathrooms, elevators, trams), abused bodies and spirits, sickness and death, melancholy (toska) and despair ${ }^{3}$. In such a world, Mayakovsky wrote in 1913, the only answer was to "lie down / bright / in linen clothing / on the soft bed of the shit of the present (nastoiashchii navoz) / and quietly / kiss the knees of the track / as the wheel of the locomotive hugs my neck". (I should note that in speaking of "the shit of the present", I am loosely translating into English the phrase "на мягкое ложе из настоящего навоза" in a way that reflects, perhaps beyond what Mayakovsky was thinking, the multiple meanings of both настоящего and навоз).

But critical negation of the "shit of the present" - a notion and experience at the heart of Bloch's conception of the workings of utopia - was entwined with a vision of an ocean of possibility greater than our normativized reality. In his futurist years, Mayakovsky treated aesthetic antinormativity as political. If utopianism is radical negation of reality as it merely is, a determination to "rattle the bars" holding back the world of possibility, to "blast open the continuum of history", Mayakovsky practiced this with less irony than other futurists. He did not like to stay within the rules of the game of épater les bourgeois. He insisted to audiences that he was no "madman" or "clown" entertaining the bourgeois crowd with desired scandal. He was more like an angry Jeremiah railing against the world's failings, sins, and false prophets. In a utopian spirit, futurism was a visceral and anarchistic rejection of every normative habit, value, and structure that stood in the way of the new. For futurists, it was right and good that the "philistine" crowd, for whom the present was the only future they could imagine, should be shocked and outraged. How else could one disrupt the dominant worldview that sees in the present only the "eternal repetition of what has already been", as Trotsky had defined the mentality of the "philistine pessimist". How else could one "leap", in Walter Benjamin's words, into the "open air of history"?

Futurist books were as antinormative in form as they were in content. A jumble of clashing typefaces and images flew across pages proclaiming an explosive end to everything old and conventional, a "slap in the face" of realism in art and reality itself. These books refused to be bound by the dead hand of the unimaginative present, embracing and championing the vital chaos of the emerging new. Commercial publishers refused to print them, Mayakovsky claimed, because "the capitalist nose smelled dynamiters in us". That is certainly how they wanted to be seen. Mayakovsky's contributions to futurist publications between 1912 and 1914 were fully in this disruptive spirit. And so was his style in these years: he regularly wore a bright yellow loose-fitting shirt, big extravagant bow-ties, and a spoon or radish on his lapel.. He was purposefully outlandish, even literally so as a gesture toward another place and time. He was at war with the present as it was given and with philistine acceptance of convention as truth: the "filthy stigmas of Your 'Common Sense' and 'good taste" that still rule "for now".

3 See especially "Noch" (1912), "Utro" (1912), "Iz ulitsy v ulitsu" (1913), "Koe-chto pro Peterburg" (1913), "Ulichnoe" (1913), "Ia" (1913), "Liubov"” (1913), and "Shumiki, Shumy, Shumishchi” (1913).

4 On anarchy, art, and Russian futurism, see: Gurianova N. The Aesthetics of Anarchy: Art and Ideology in the Early Russian Avant-Garde. Berkeley, 2012. Chapter 1.

${ }^{5}$ Maiakovskii V. V. Ia sam (1922) // Maiakovskii V. V. Izbrannye sochineniia. In 2 vols. Moscow, 1981. Vol. 1. P. 45.

${ }^{6}$ Burliuk D., Kruchenykh A., Maiakovskii V., Khlebnikov V. Poshchechina obshchestvenomu vkusu // Manifesty i programmy russkikh futuristov / ed. by Vladimir Markov. Munich, 1967. P. 50-51. 
Deliverance from the dark reality of the present was brought by the counterreality of "Vladimir Mayakovsky" - not his actual self, still bound to the "customary land of reality," but his persona as a mythic poet, revolutionary artist, and redeeming savior, as the utopian antithesis of the merely factual reality of the present. It was this "Mayakovsky" who would inspire humanity to free themselves from the darkness, derail the approaching locomotive of reality and necessity, and leap into the free air of history. In December 1913, Mayakovsky staged his play Vladimir Mayakovsky: A Tragedy as part of a futurist theatrical event in St. Petersburg, in alternation with the more famous avant-garde opera Victory over the Sun. A poet named Mayakovsky, "perhaps the last poet", appears in "the spider-web of streets" during a "beggars' holiday". He sees crippled men and madness everywhere. He sees that men and women "in the land of cities" are ruled by "soulless things" with "blocked emotions". It is in this dark present that he considers lying down on "the soft bed of the shit of the present" with his neck ready to be embraced by the on-coming train. But he decides that rather than die for the world, he would incite mass refusal to accept the "shit of the present". Frustration, madness, and anger - the emotional experience of the living darkness of the present - becomes revolution. Even material things rebel against their slavery to "old lady time", the ultimate ruler, who had named and confined all things.

In the new world created by this revolution, the poet Mayakovsky, wearing toga and laurel wreath, is worshiped as a ruling prince. But this new world turns out to be a dystopic extension of the old: built around the exchange of money and sex. Plus, everyday life was "dull" and "melancholy". Unable to endure this disappointing new reality, though its citizens seem not to care and bring the poet tears they feel they no longer have any use for, the poet gathers these useless tears in a suitcase and journeys to the farthest north to deposit them at the feed of "the dark god of storms / at the very source of beastly faiths" (or, perhaps, "the source of the sign of the beast", as one scholar translated this ambiguous final line). The many allusions to the poet as Christ redeeming human suffering become fully explicit in this culmination. "Come unto me", the poet Mayakovsky proclaims to the world, "all who have shattered the silence / who find / the noose of our days too tight". He accepts the pain of others to be crucified on his own "cross of laughter" - an image combining radical negation, suffering, and a promise of salvation. He declares himself ready to die in order to carry away the burden of people's tears to his own Golgotha ${ }^{7}$.

Mayakovsky was among the bold (or mad) minority who embraced war in 1914 for its anarchic vitality and apocalyptic possibility. This was attitude shared by radicals like Trotsky, as we have seen, and by many avant-garde artists, for whom the image of war had already become a metaphor for the death of the old that would finally allow the birth of the new - the moment "everyone is waiting for", as another futurist wrote in the first study of Mayakovsky's poetry, "when the present will finally do away with itself and open

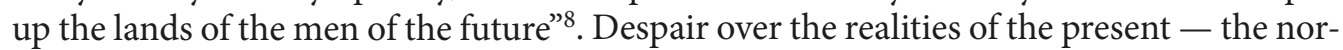
mativized state of emergency - had inspired a utopian desire for a different reality and a utopian belief in its possibility.

Mayakovsky defended his initial attraction to war in articles published in a Moscow newspaper toward the end of 1914. "Violence in history is always a step toward perfection,

7 Maiakovskii V. Tragediia // Maiakovskii V. V. Izbrannye sochineniia. In 2 vols. Moscow, 1981. Vol.2. P. 7-23.

${ }^{8}$ Gurianova N. The Aesthetics of Anarchy: Art and Ideology in the Early Russian Avant-Garde. Chapter 7. The quotation is from: Kruchenykh A. Stikhi Maiakovskogo. Moscow, 1914. P. 167. 
toward the ideal kingdom," he declared. War redraws boundaries and remakes "human psychology". War "is not senseless murder, but a poem about the liberated and exalted soul", inspired by feelings so different from those of normal times. In these conditions, the "human essence is changing. The powerful people of the future are being born". Therefore, art must embrace the "magnificence" of war, even "ride on the gun-carriage wearing a hat

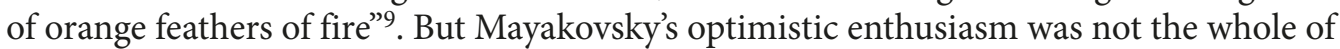
his feelings about the war, especially when he shifted his gaze from desires and ideas to lived experience. He also wrote, in these same months, dark poems about spilled blood, death, and unbearable loss - such as a grieving mother lashing out at the "newspapers' eyes" and the hysterical patriotism of the public so at odds with her loss ${ }^{10}$.

During the summer of 1915, working on his deeply personal poem, "A Cloud in Trousers", Mayakovsky again envisioned a revolution entwined symbolically with the passion of Christ. In the utopian mode, Mayakovsky's Christ offered salvation from the present world of suffering, oppression, darkness, and death by means of a new truth from beyond the limits of reality and possibility as they were assumed to be:

Beyond where man's meager vision breaks off,
a certain year approaches
at the head of hungry hordes,
wearing the thorny crown of revolutions.
I shall be, for you, its precursor;
I am everywhere there is pain:
in every drop of the stream of tears,
I've nailed myself to the cross.
Nothing can be forgiven anymore ${ }^{11}$.

In 1916, Mayakovsky worked on a pair of long poems, "War and the Universe" (Voina i mir) and "Man" (Chelovek, or Person), which suggest something of his inner struggle to make sense of the present and the future. He would later describe this as a conflict between the hope in his mind and the doubt in his spirit: "In my head 'War and the Universe' unfolded. In my heart - 'Man"'12. The work of his head was a confident prophecy of a transformed world, of perfection born in violence, of an epic utopia. The poem begins in the present world of urban gluttony, lust, and sickness. The "soundtrack" of that life, as we would say now, was the tango - indicated by lines of music interspersed in the text. (The tango had become, for the prewar Russian press, a symbol of cosmopolitan decadence.) War disrupts this world, though not as a vital and necessary devastation of the old but as the senseless bloodshed of gladiators in a pagan Coliseum. In the face of such horrors, the "angels tremble" and the gods - "Sabaoth / Buddha / Allah / Jehovah" - flee the heavens. For this and for all human suffering, the poem declares, everyone is guilty. The music in the text suitably changes to an Orthodox chant for the dead.

9 Maiakovskii V.V. Shtatskaia shrapnel' // Maiakovskii V.V. Polnoe sobranie sochinenii. In 13 vols. Moscow, 1955. Vol. 1. P. 302-310; Maiakovskii V. V. Budetliane // Ibid. P.329-332.

${ }^{10}$ Notably, "War is Declared" and "Mama and the Evening Killed by the Germans".

11 Maiakovskii V. V. Oblako v shtanakh [A cloud in pants] // Maiakovskii V. V. Izbrannye sochineniia. In 2 vols. Moscow, 1981. Vol. 2. 185, 409. In 1918, Mayakovsky revised the phrase "a certain year" (kotoryi to god) to "1916". See also: Brown E. Mayakovsky: A Poet in the Revolution. Princeton, 1973. P. 115.

12 Maiakovskii V. V. Ia sam (1922). P. 46. 
But out of this catastrophe comes a new and redeemed world. In this utopia - the first section of the poem to appear in print, published by Maxim Gorky just after the February revolution - "there will be no one to torment man. / People will be born, / real people, / much more merciful and better than god". This new and "redeemed" world arrives apocalyptically: "A whisper. / The world / unclenches its black lips. / Louder / A hurricane / roars awake," and the dead arise. Every nation brings its natural gifts to this new world for the pleasure and glory of united humanity. America brings the power of machines, Italy its warm nights, Africa the hot sun, Greece the beautiful bodies of youth, Germany philosophy, and France love. Russia "opens its heart in a fiery hymn". The very air and mood are renewed. Nature is transfigured: the sea, "so stormy yesterday / lies down by your feet / and purrs." Machines of war "sit before one's house / on the lawn / peacefully trimming the grass". And every sin, across all time, is forgiven through love: "Cain / under a tree / plays checkers with Christ." This was also a personal utopia, overcoming the darkness in Mayakovsky's life caused by his love for Lilya Brik, who was married to a close friend: in this transformed world, he and his beloved are together ${ }^{13}$.

The poem "Man" responded to these dreams and promises with gloomy doubt shifting from the utopia of hope to the utopia of radical negation, the repudiation of a reality that is impossible to accept. Money, Mayakovsky believed, is the heart of darkness of the present, as it has been for so many utopias, including Thomas More's original. Money stands for everything objective, quantifiable, and conventional, the antithesis of life, emotion, thinking, music, and poetry. "Man" is a story of the birth, experience, passion, ascension to heaven, and return to earth of the poet "Mayakovsky". The poet is "shackled" and "captive" in a world where money is king and defended by "law" and "religion." In a foaming sea of money, "geniuses, hens, horses, and violins drown. / Elephants drown. / Little things drown".

And so, as it were, he leaps into the open air: thinking of suicide as gesture of protest, "Mayakovsky" ascends to heaven, physically rising from the street toward the cosmos literally toward "dem freien Himmel" - as ordinary passersby cry out in astonishment. But the promised bliss of heaven - the archetypal closed utopia of perfection - is disappointing: it is dull, routine, and cold, a cloudland of "cleansed smoothness" where everything "is in frightfully good order / at rest / in ranks," and people lack bodies and so also lack hearts. Time moves slowly in paradise, until finally, after many thousands of years, the poet Mayakovsky rouses himself and returns to earth. Surely by now, the world had become new, a true paradise? But no, nothing had changed. The passage of time had not brought happiness any more than had his passage into the place beyond time, life, and death. This was the final and worst disappointment. Mayakovsky, the "Man" of the title, realizes that there is nowhere left to go, apart from refusing to stay. Heaven and earth have failed. Space and time have left him adrift. All that remains is to wander for eternity among planets and stars, in the nowhere outside of everything ${ }^{14}$.

As can be seen, time was an obsession for Mayakovsky. Time has also long been at the heart of modern utopian thinking - the new and better world often located in another time rather than a distant place. But time could be as much an obstacle as a path, when

${ }^{13}$ Maiakovskii V. V. Voina i mir (1915-1916) // Maiakovskii V. V. Izbrannye sochineniia. In 2 vols. Moscow, 1981. Vol. 2. P. 51-79.

${ }^{14}$ Maiakovskii V. V. Chelovek (1916-1917) // Maiakovskii V. V. Izbrannye sochineniia. In 2 vols. Moscow, 1981. Vol.2. P. 80-105. 
stuck in its conventional steady pace. Most often in his prerevolutionary poems, time was normative and negative, holding back the future, crushing it under the weight of everyday reality: a "lame icon dauber," an "old woman," a "fetter" and a "chain" yoking man to the present ${ }^{15}$. During the war, Mayakovsky seemed to despair of the possibility of escaping the heavy chains of time. Even after "thousands and millions" of years, he wrote in "Man", nothing on earth would be different, the "terrible avalanche of years" would bury every possibility and hope ${ }^{16}$.

The 1917 revolution, it seemed, broke this old temporality open. Suddenly and unexpectedly, Mayakovsky wrote in April, in his "poeto-chronicle" of the revolution, "the thousand-year old 'Before' has collapsed, / Today, the whole basis of the world has been altered" 17 . When the Bolsheviks came to power in October, he rushed to the party's headquarters to declare himself ready "to do anything" for "my revolution" ${ }^{18}$. But the government, and Lenin in particular, quickly lost patience with the more-radical-than-everyone-else stance of artists like Mayakovsky. That these "left artists" were "unintelligible" to workers and peasants was only the surface of a deeper error: their nihilistic rejection of the entirety of the old culture at a time when, as Lenin wrote, the first cultural task of the revolutionary state must be "grasp all the culture that capitalism has left and build socialism from it. It is necessary to grasp all the science and technology, all the knowledge and art. With this, we will be able to build the life of a communist society"19. But radical artists like Mayakovsky believed that cultural revolution demanded destruction of the shackles of the normative old, which was holding the world back from leaping into the new. Typical was Mayakovsky's "Order to the Army of Art," which appeared in the first issue in December 1918 of the weekly newspaper of communist artists, Art of the Commune (Iskusstvo kommuny):

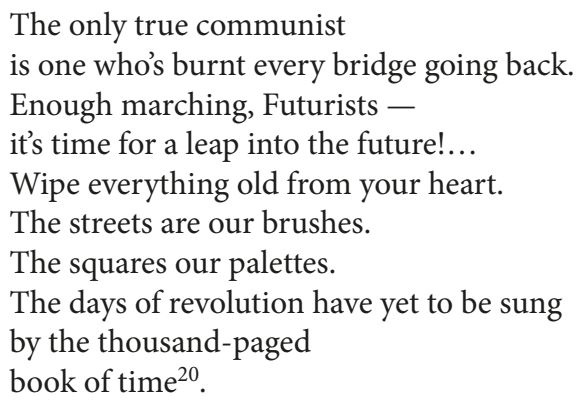

But the old time refused to let go - the bridges going back remained intact and the locomotive kept coming. So, like many others, including Trotsky, Mayakovsky embraced violence and terror (if only poetically) to shatter the old. Already at the end of 1918, in an editorial manifesto in verse in the second issue of Art of the Commune, Mayakovsky added

15 From “A Few Words about Myself” (1913), "Vladimir Mayakovsky” (1913), and “Man” (1916-17).

${ }_{16}$ Maiakovskii V.V. Chelovek (1916-1917). P. 95.

17 Maiakovskii V.V. Revoliutsiia: poetokhronika (17 April 1917) // Maiakovskii V.V. Izbrannye sochineniia. In 2 vols. Moscow, 1981. Vol. 1. P. 95-101.

18 Maiakovskii V.V. Ia sam (1922). P. 47.

19 Lenin V. I. Successes and Difficulties of Soviet Power (1919) // Lenin V. I. Polnoe sobranie sochinenii. $5^{\text {th }}$ ed. Moscow, 1969. Vol.38. P. 55. On Lenin's "anti-iconoclasm" see also: Stites R. Revolutionary Dreams: Utopian Vision and Revolutionary Life in the Russian Revolution. Oxford, 1989. P. 76-78.

${ }^{20}$ Maiakovskii V. V. Prikaz po armii iskusstva // Maiakovskii V.V. Izbrannye sochineniia. In 2 vols. Moscow, 1981. Vol. 1. P. 106-107. 
metaphors of violence to his millenarian "leap into the future". It is not enough to put only political enemies "up against the wall". If we truly "seek the future," we must also kill the White Guards of art: "It's time / for bullets / To whistle on museum walls. / Shoot at the old from your hundred-inch cannon-throats, / Sow death in the enemy's camp"21. By 1919, his tone became almost desperate as the old held on. So, in culture as on the actually battlefields of the civil war, anything less than the extermination of the representative of the old might allow their return to power. "We / cannot just fantasize / about the new order / but have to dynamite the old... / With heat, / with burning, / with iron, / with light; / scorch, / burn, / cut, / raze!... / If it's old - kill it. / Use their skulls as ashtrays! / In a savage rout / we'll wash away the old / and thunder a new / myth across the world. / We'll kick down / the fence of time" 22 . But that "fence" would not fall.

The old time was linked to the old byt - the normative routines and habits of everyday life. The old byt embodied the past in the present, the slow and repetitive march of ordinary time. By the late 1920s, this was the "time-the-reptile" and the "monster-byt" that refused to $\mathrm{die}^{23}$. As Trotsky and Kollontai would also find in their struggles against conventional byt during the 1920s, the monster refused to die. Mayakovsky already worried about this in a melancholy poem he wrote toward the end of 1920, as the battles of the civil war were winding down but before the major compromises of NEP. "The storms of revolution have subsided. / The Soviet muddle is covered in slime. / From behind the back of Soviet Russia / has crawled out / purring / the philistine." Karl Marx, from his portrait on the wall, "looks and looks all around, / and suddenly opens his mouth / and shouts: I the revolution is snared in a web of ordinariness [obyvatel'shchina], / of a commonplace everyday life [obyvatel'skii byt] more terrible than Wrangel"24. The reptilian monster of normative time was all that remained. Life was fettered and chained to the present. A "leap" from necessity to freedom was impossible.

We could end on this note of disenchantment. We know that in 1930 Mayakovsky shot himself through the heart. Scholars have interpreted his suicide, so often imagined in his writings, as a "refusal to bow to byt and time," as an "acknowledgment on his own flesh and bone of the total capitulation of the future to the might of the past" 25 . Mayakovsky famously offered his own ambiguous explanation in his suicide note: "Love's boat / has smashed against byt"26. He was partly speaking literally about love, about his own difficult personal life. But he was also commenting, as were other disenchanted idealists (which by 1930 included Trotsky and Kollontai in different ways), about the times: "love's boat" as the revolution crashing against ordinary life (byt), against the "merely factual" world as it was given, against "necessity". Ernst Bloch, whose definition of the utopian impulse has shaped my arguments, rarely commented directly on the Russian revolution. But one

${ }^{21}$ Maiakovskii V. V. Radovat'sia rano // Maiakovskii V.V. Izbrannye sochineniia. In 2 vols. Moscow, 1981, vol. 1, p. 108.

22 Maiakovskii V.V. 150,000,000 (1919-1920) // Maiakovskii V.V. Izbrannye sochineniia. In 2 vols. Moscow, 1981, vol. 2, pp. 112-113.

${ }^{23}$ Maiakovskii V.V. Zastrel'shchik (1929) // Maiakovskii V. V. Polnoe sobranie sochinenii. In 13 vols. Moscow, 1958. Vol. 10. P. 87; and "Marsh vremeni" from "Bania" (1919-1930) (Maiakovskii V.V. Izbrannye sochineniia. In 2 vols. Moscow, 1981. Vol.2. P. 523-524).

${ }^{24}$ Maiakovskii V. V. O driane (1920-1921) // Maiakovskii V.V. Polnoe sobranie sochinenii. In 13 vols. Moscow, 1956. Vol. 2. P. 73-75, 498.

25 Stahlberger L. The Symbolic System of Mayakovsky. The Hague, 1964. P.135; Thompson R.D. B. Mayakovsky and his Time Imagery // Slavonic and East European Review.1970. Vol. 48 (2). P. 200.

${ }^{26}$ Maiakovskii V. V. Polnoe sobranie sochinenii. In 13 vols. Moscow, 1961. Vol. 1.P. 138. 
comment is telling in this darkening light: the revolution was a time, he concluded in 1923, when "doors opened; but, of course, they soon shut"27.

We could interpret these dark outcomes differently, however, by recalling that utopia-as negation of the darkness, as the open air of historical possibility, as a leap to the kingdom of freedom - is always "infinitely improbable" but no less inevitable and necessary for that, as Arendt argued about freedom. Or, in Walter Benjamin's words, the utopian spirit is a "flash" and a "splinter" of "messianic time," which one can best see and grasp precisely when catastrophe is strongest ${ }^{28}$.

In other words, we might view the Russian revolution less as a story of trying and failing to create a perfect society, and more as a method and a practice that disrupted a dark and catastrophic present with the force of what should be and therefore could be. Metaphorically - for the revolution loved metaphors - this means our understanding, even appreciating, the utopian "leap" even as we recognize the dystopian and catastrophic landing, that we also study the briefly opened door to the kingdom of freedom, the pulled emergency break, the rattling of the bars.

\section{References}

Brown E. Mayakovsky: A Poet in the Revolution. Princeton, Princeton University Press, 1973, 386 p.

Bloch E. The Spirit of Utopia. Stanford, Stanford University Press, 2000, 320 p.

Gurianova N. The Aesthetics of Anarchy: Art and Ideology in the Early Russian Avant-Garde. Berkeley, University of California Press, 2012, 360 p.

Jangfeldt B. Majakovskij and Futurism, 1917-1921. Stockholm, Almqvist \& Wiksell International Publ., $1976,133 \mathrm{p}$.

Jangfeldt B. Mayakovsky: A Biography. Chicago, University of Chicago Press, 2014, 616 p.

Markov V. Russian Futurism: A History. Berkeley, University of California Press, 1968, 467 p.

Perloff M. The Futurist Moment: Avant-Garde, Avant Guerre, and the Language of Rupture. Chicago, University of Chicago Press, 2003, 336 p.

Stites R. Revolutionary Dreams: Utopian Vision and Revolutionary Life in the Russian Revolution. Oxford, Oxford University Press, 1989, 344 p.

Stahlberger L. The Symbolic System of Mayakovsky. The Hague; Paris, Mouton Publ., 1964, 106 p.

Terras V. Vladimir Mayakovsky. Boston, Twayne, 1983, 170 p.

Thompson R. D. B. Mayakovsky and his Time Imagery. Slavonic and East European Review, 1970, vol. 48, no. 111 (April), pp. 181-200.

27 Bloch E. The Spirit of Utopia. Stanford, 2000. P. 1.

28 Benjamin, "On the Concept of History". 